\title{
Networking of small cities as a contribution for sustainable regional development
}

\author{
Matvey S. Oborin \\ Perm Institute (branch) of the Plekhanov Russian University \\ of Economics \\ Perm State National Research University \\ Perm State Agro-Technological University named after \\ Academician D.N. Pryanishnikov \\ Perm, Russia \\ recreachin@rambler.ru
}

\author{
Marina Y. Sheresheva \\ Lomonosov Moscow State University \\ Faculty of Economics \\ Moscow, Russia \\ m.sheresheva@gmail.com
}

\begin{abstract}
The article discusses the role of small cities networking in increasing the social and economic regional development efficiency. Specific nature of networking at different management levels is considered, different approaches to the definition of network elements and participants are discussed. Different types of spatial and economic interaction are characterized, a model for participation of small cities with different degree of network embeddedness is proposed.
\end{abstract}

Key words: networking, small cities, model, indicators, region, institutional environment

\section{INTRODUCTION}

Nowadays, there is discussion at various levels of management concerning the most effective models of social and economic regional development that could facilitate the solution of urgent issues facing Russian regions. The practice of centralized regulation and control that is still intrinsic to many regions needs improvement and correlation by means of market mechanisms. In particular, taking into account the interests of territory stakeholders is of crucial importance, including the residents that are consumers of material goods and services.

Networks are now among the most effective new management models. The modern conditions of doing business boost different forms of networking that help to combine resources in co-creation of products and services, to increase competitiveness and thus to gain economic effectiveness.

The first attempts to apply the network theory to social and economic life refer to 1960-1970s. Now there is plenty of academic literature discussing different aspects of network phenomena in economics and management. The social networks theory $[1 ; 2]$, the industrial organization theory $[3$; 4], and the new institutional economic theory [5; 6] make together a solid base for research in the field. In particular, networking at the regional and city level is in the focus of academic interest $[7 ; 8 ; 9 ; 10]$.

Empirical studies on cross-country samples have confirmed the significant impact of institutional environment on investment activity $[11 ; 12 ; 13 ; 14 ; 15]$. The results of assessing the quality of economic institutions in different countries served as a basis for development and modification of national legislation systems, and for improving quality of public administration. However, there are few studies focused on the city level, which makes it difficult to develop and implement local institutional projects. This article aims to fill this gap by analyzing the institutional environment of small Russian cities and its role in investment climate improvement.

\section{MATERIALS AND METHODS (MODEL)}

Dialectical method and systematic approach to the analysis make together the methodological framework of the study. Dialectical method allowed us to draw sound conclusions on possible structural problems and trends, as well as on characteristics of the contemporary institutional environment. Systematic approach was helpful to conduct a comprehensive analysis of the socio-economic situation, taking into account the existing specialization of territories under consideration, as well as infrastructure characteristics. Formal logical method helped to analyze and interpret relevant facts based on the information of various statistical nature. The case study was also used to understand situation in small cities of Tula, Vladimir and Perm regions, with the aim to offer recommendations based on their specialization.

\section{RESULTS AND DISCUSSION}

In the contemporary world economy, there is a shift towards new approaches to design and management cities, urban-type settlements and villages $[16 ; 17 ; 18]$. The underlying factors of sustainable urban development $[19 ; 20]$, and the role of cities in ensuring sustainable regional development, has become an important subject of study [21; 22]. There is increasing evidence that the issues facing smaller cities may be very different from those facing a large city [23] but the resilience of small cities is equally important to the well-being of any region in the world $[24 ; 25$; 26]. 
The economic development of small cities in many countries faced with economic decline and outflow of population [27]. While formerly small cities were tending to rely on the use of internal opportunities and resources, in the last decades they look for external financing. In this connection, creation of favorable conditions for investments and increase the interest in small cities as places for living and tourist destinations is in the focus of regional and municipal authorities.

There are a number of issues, including social and economic, as well as managerial, communication, etc., that accompany the development of urban space as part of the regional economic space. The networking of cities leads to a more balanced territorial development, since it involves not only the city itself, but also the vast surrounding rural areas [28]. Moreover, the network coordination mechanism creates a basis for cooperation of small cities in several directions, including infrastructure development, exchange of best management practices, labor resources and competencies, joint projects implementation. Therefore, it makes more sense for small cities not to act separately but to collaborate within inter-municipality networks $[29 ; 30]$.

In case of inter-municipality networking, each city acts as an independent actor developing own development strategy, both competing and cooperating with other cities [31]. Formal connections between actors are necessary but insufficient for the emergence of sustainable relationships that can lead to efficient networking. In addition, the existence of common views and values is necessary to achieve high efficiency of network interaction.

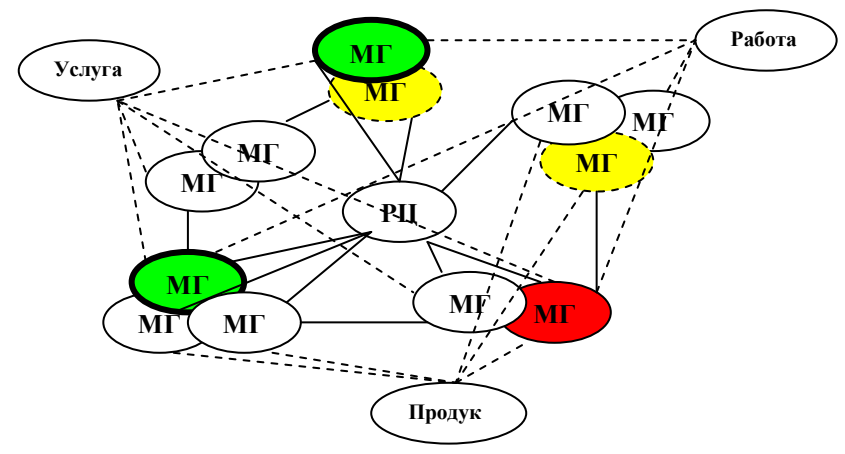

Fig. 1. Network model for small cities with different types of spatial and economic contacts [32].

In the Perm region, Vladimir region, and Tula region there are examples of small cities with industrial, agricultural, tourist and recreational specialization. This allows their participation in networks, based on organization of logistics and transport connections that enhance accessibility to resources and allocation of results for business and for the residents.

To determine the most effective types of relationships between cities, it is important to take into account peculiarities of different network types, as well as the specifics of local institutional environment. Local norms and rules are meaningful part of this environment; at the same time, it is impossible to neglect the substantial influence of regional and federal level institutions, both formal and informal ones. These institutions together create conditions for living in small cities, as well as for doing business and attracting investments.

The quality of institutions and the investment climate are quite different in Russian regions. The analysis of municipal statistics confirms uneven distribution of investment flows within regions, where almost all investments are concentrated in largest cities, primarily in the regional centers. In addition, the problems of small cities are largely due to the lack of institutional and managerial competencies needed to create a favorable investment climate [33].

One can state that institutional environment of Russian small cities serves now as a factor reducing their investment attractiveness. Increase in costs caused by increase of tax burden reduces the profitability of potential investments and therefore their efficiency. The low quality of institutions that ensure property rights protection also leads to additional costs for investors.

On the contrary, institutions that ensure state participation in project financing (in the form of subsidies or public-private partnerships) is able to reduce investor costs and to increases the investment attractiveness. Therefore, state programs designed for the social and economic development of the territory are of high importance. These programs should take in account existing potential and needs of small cities as important part of regional ecosystem. In this regard, detailed analysis of each settlement is crucial that can help to achieve a number of important tasks:

- to assess social and economic situation in the city, including comparison with other settlements;

- to identify specific advantages and disadvantages of a given settlement/area;

- to study the existing base for formation, allocation, and use of resources;

- to determine opportunities for resource provision optimization.

Concerning small cities institutional environment, the institutional matrix concept is applicable [34; 35]. The institutional matrix is a stable, historically established system of basic institutions that regulate the interrelated functioning of the main social spheres (economic, political and ideological). The economic sphere is engaged in the reproduction of resources, the political sphere is responsible for the organization and form of governance, the ideological sphere embraces the formation of social values and attitudes.

There are two main types of institutional matrix. Matrix $\mathrm{X}$, characterized by the prevalence of collective ideas over personal interests and values, is more applicable to the Eastern countries. For the matrix Y, represented mainly in Western countries, the prevalence of personal interests over collective interests is characteristic.

The economies of scope, complementarities, and network externalities of an institutional matrix make institutional change overwhelmingly incremental and path dependent [36]. 
The institutional matrix concept is applicable to understanding cities as a set of social institutions.

In relation to cities, there are five basic groups of institutions:

- Spatial organization of a city - a set of urban institutions related to construction and urban planning;

- Self-government - a set of institutions for expression of public will, political and social position of city residents, institutions of municipal elections;

- Economy - a set of economic institutions of society, primarily industry and trade, as well as other institutions engaged in allocation and operation of economic resources of the city;

- Sacred component - a set of institutions that characterize the symbolism of agglomeration and are carriers of sacred meaning, like cultural and historical heritage of cities;

- Integration of urban society - a set of institutions that promote the inclusion of city residents in an active social life.

Taking an example of the Perm region infrastructure, which forms a tourist and recreational specialization, we can state that a large number of infrastructure facilities in the regional spa \& recreation complex are a result of their versatile specialization and year-round accommodation of tourists. At present, the sanatorium-and-spa organizations, in addition to quality treatment and rehabilitation, have to provide a high level of service and leisure. This leads to the expansion of the means of additional recreational infrastructure. Among these objects in the resorts are hairdressers, rental shops, swimming pools, baths, saunas, gyms, etc.

Based on the analysis of the available data, we can see that the number of hairdressing salons in 2008-2009 was decreasing, since the financial crisis affected all spheres of human life. On the contrary, there was a backward gradual increase in 2010-2013. In 2010-2015, there was an increase in the number of saunas and rental of sports equipment, due to the expansion of spa \& resort activities. There are now 17 swimming pools in spa \& resort organizations of the Perm region. This indicator stood unchanged in 2011-2015, since there was no significant increase in the construction of the infrastructure complex. The number of tennis courts and gyms was gradually increasing in 2011-2015, due to the transition of a large number of spa \& resort organizations into private ownership.

One can also underline increasing investments in the objects under construction, namely sports facilities. This may be a result of the fashion on healthy lifestyle. For example, large sports and recreation centers, built over the past 2-3 years at the resorts of Ust'-Kachka and Klyuchi, worth more than 350 million rubles.

Analyzing the change in the Perm region spa \& resort infrastructure in 2002-2015, one can see the annual increase in spa \& resort organizations, from 171 in 2002 to 248 in 2015. This can be explained by the transition of the resort facilities to private funds that actively boost their development with the aim to increase overall competitiveness. As a result, the infrastructure improves.

Another example is improvement of Vladimir region tourist infrastructure that leads to economic diversification of small single-industry cities. Increased transport accessibility due to reconstruction of road network in the Vladimir region made it possible to support tourism industry development in peripheral districts, with district centers in small cities Sobinka, Melenki, Sudogda. These districts have enough cultural and recreational potential but lack sufficient infrastructure facilities. This prevented them to become to be attractive part of different tourist routes.

Now this issue attracts constant attention of the regional authorities. The Support Program for the domestic and incoming tourism development in the Vladimir Oblast in 2016-2020 provides small single-industry cities and peripheral districts with a number of special grants to support developing valuable products for tourists. For instance, the celebration of the 850th anniversary of Gorokhovets was chosen to embed this historical city into tourist routes, to increase the recognition of the city as a tourist destination, as well as to resolve urgent infrastructure problems, and to restore and preserve objects of cultural and historical heritage.

Taking into account the experience of touristic small cities in the Vladimir region, included in the Golden Ring of Russia, regional and municipal authorities collaborate to develop various new types of tourism and tourist routes by different programs connecting traditional tourist destinations with previously depressed small cities. There are more than 350 events in the regional Annual event calendar. The Gastronomy Map of Vladimir Region, The Musical Expedition, Folk Arts and Crafts on the Tourist Map of the Vladimir Region, The Green Pearl of Vladimir Region and other projects and initiatives embed small cities into tourist network of Vladimir region.

\section{CONCLUSION}

Networking of small cities is of high importance for social and economic regional development. Based on regional practices of networking, it is advisable to include depressed territories in developed networks. Key areas of small cities networking are trade, transport, recreation, and agriculture, since there are prerequisites for further strengthening these types of specialization as profile ones.

The practice of network interaction has revealed the crucial role of infrastructure and institutional environment for the development of small cities as important members of regional ecosystem. Networking of small cities with more developed centers is a promising direction, as it allows them to participate in mutually beneficial allocation and exchange of resources, to increase the attractiveness and accessibility, to modernize the infrastructure taking into account peculiarities of demand, as well as current and prospective specialization of each city. 


\section{References}

[1] Vismara, S. (2016). Equity retention and social network theory in equity crowdfunding. Small Business Economics, 46(4), 579-590.

[2] Koskela-Huotari, K., Siltaloppi, J., \& Vargo, S. L. (2015). Understanding institutional complexity in service ecosystems: insights from social network theory and systems thinking. In The 2015 Naples Forum on Service, 9-12, June, 2015, Naples, Italy.

[3] Waldman, D., \& Jensen, E. (2016). Industrial organization: theory and practice. Routledge.

[4] Yeung, H. W. C., \& Coe, N. (2015). Toward a dynamic theory of global production networks. Economic Geography, 91(1), 29-58.

[5] Menard, C., \& Shirley, M. M. (2014). The future of new institutional economics: from early intuitions to a new paradigm? Journal of Institutional Economics, 10(4), 541-565.

[6] Richter, R. (2015). New economic sociology and new institutional economics. In Essays on New Institutional Economics (pp. 51-75). Springer, Cham.

[7] Bel, G., \& Warner, M. E. (2015). Inter-municipal cooperation and costs: Expectations and evidence. Public Administration, 93(1), 52-67.

[8] Broekel, T., Brenner, T., \& Buerger, M. (2015). An investigation of the relation between cooperation intensity and the innovative success of German regions. Spatial Economic Analysis, 10(1), 52-78.

[9] Camagni, R. (2017). From city hierarchy to city network: reflections about an emerging paradigm. In Seminal Studies in Regional and Urban Economics (pp. 183-202). Springer, Cham.

[10] Klaster, E., \& Muntslag, D. (2016). Regional 'meta-networks' for Dutch public-policy implementation: A mixed-methods field study. In Academy of Management Proceedings. No. 1, p. 11256. Academy of Management.

[11] Ali, F. A., Fiess, N., MacDonald, R. (2010). Do institutions matter for foreign direct investment?. Open Economies Review, 21(2), 201-219.

[12] Aron, J. (2000). Growth and institutions: a review of the evidence. The World Bank Research Observer, 15(1), 99-135.

[13] Dawson, J. W. (1998). Institutions, Investment, and Growth: New Cross-country and Panel Data Evidence. Economic inquiry, 36(4), 603619.

[14] Henisz, W. J. (2002). The institutional environment for infrastructure investment. Industrial and corporate change, 11(2), 355-389.

[15] Varsakelis, N. C. (2001). The impact of patent protection, economy openness and national culture on $R \& D$ investment: a cross-country empirical investigation. Research policy, 30(7), 1059-1068.

[16] Cross J. A. (2001). Megacities and small towns: different nersnectives on hazard vulnerabilitv. Global Environmental Change Part B: Environmental Hazards, 3(2), 63-80.

[17] Campbell T. (2013). Beyond smart cities: how cities network, learn and innovate. Routledge.

[18] Chadwick G. (2016). Models of Urban \& Regional Systems in Develoning Countries: Some Theories and Their Application in Physical Planning (Vol. 36). Elsevier.

[19] Satterthwaite D. (1997). Sustainable cities or cities that contribute to sustainable development? Urban studies, 34(10), 1667-1691.
[20] Haughton G.. Hunter C. (2004). Sustainable cities. Routledge; Nijkamp P., Perrels A. (2014). Sustainable cities in Europe. Routledge.

[21] Jacobs J. (2016). The economy of cities. Vintage.

[22] Calthorpe P., Fulton W. (2001). The regional city. Island Press.

[23] Haughton, G., \& Hunter, C. (2004). Sustainable cities. Routledge.

[24] Courtney P., Mayfield L., Tranter R., Jones P., Errington A. (2007). Small towns as 'sub-poles' in English rural development: Investigating rural-urban linkages using sub-regional social accounting matrices. Geoforum, 38(6), 1219-1232.

[25] Courtney, P., \& Errington, A. (2000). The role of small towns in the local economy and some implications for development policy. Local Economy, 15(4), 280-301.

[26] Knox P., \& Mayer H. (2013). Small town sustainability: Economic, social, and environmental innovation. Walter de Gruyter.

[27] Martinez-Fernandez, C., Audirac, I., Fol, S., \& Cunningham-Sabot, E. (2012). Shrinking cities: Urban challenges of globalization. International Journal of Urban and Regional Research, 36(2), 213-225.

[28] Christiaensen, L., De Weerdt, J., \& Todo, Y. (2013). Urbanization and poverty reduction--the role of rural diversification and secondary towns. Agricultural Economics. 44(4-5), 435-447.

[29] Oborin, M.S., Pakhalov, A.M., \& Sheresheva, M.Y. (2017). Effektivnost'strategicheskogo planirovaniya razvitiya malykh gorodov na osnove setevogo mekhanizma koordinatsii [The effectiveness o strategic planning for small cities' development based on the network coordination mechanism. Vestnik Moskovskogo universiteta. Seriya, 6. Economics $=$ Moscow University Economic Bulletin (4), 100-116.

[30] Mingaleva, Z.A., Sheresheva, M.Y., Oborin, M.S., Gvarliani, T.E. (2017). Networking of small cities to gain sustainability. Entrepreneurship and Sustainability Issues. 5 (1), 140-156.

[31] Camagni, R., \& Capello, R. (2004). The city network paradigm: theory and empirical evidence. Contributions to Economic Analysis, 266, 495529.

[32] Oborin, M.S., Sheresheva, M.Y.., Ivanov, N.A. Obosnovanie strategicheskih orientirov social'no-jekonomicheskogo razvitija malyh gorodov Rossii [Grounds for strategic targets of socio-economic development of Russian towns]. Vestnik Permskogo universiteta. Ser. «Jekonomika» = Perm University Herald. Economy. 2017. 12(3), 437-452.

[33] Oborin, M.S., Sheresheva, M.Y., \& Pakhalov, A.M. (2017). Institucional'naja sreda kak faktor formirovanija investicionnogo klimata malyh gorodov Rossii [Institutional envirnment as a factor for forming investment climate of Russian towns]. Ars Administrandi. 9(3), 370394.

[34] North, D. C. (1993). Institutional change: a framework of analysis. Institutional change: Theory and empirical findings, 35-46.

[35] Casalet, M. (2000). The institutional matrix and its main functional activities supporting innovation. In Developing innovation systems: México in a global context, 243-261.

[36] North, D.C. (1995). The new institutional economics and third world developmentt, 21, 1-8. 